\title{
Testing the Photostability of Acetylated and Boiled Linseed Oil-coated Common Hornbeam (Carpinus betulus L.) Wood
}

\author{
Fanni FODOR ${ }^{*}$ - Róbert NÉMETH \\ Institute of Wood Science, Simonyi Károly Faculty of Engineering, Wood Sciences and Applied Arts, \\ University of Sopron, Sopron, Hungary
}

\begin{abstract}
In this study, the effect of acetylation and coating with boiled linseed oil was evaluated concerning the photodegradation of common hornbeam wood (Carpinus betulus L.). To measure colour stability, a 10-month-long outdoor weather resistance test without soil contact was performed as well as artificial aging using a 200 hour mercury-vapour lamp irradiation test. The measurements were done on hornbeam, acetylated hornbeam, boiled linseed oil-treated hornbeam, and acetylated and boiled linseed oil-treated hornbeam samples. The control and treated samples' colour change was determined by comparing them to the original colour in all cases. The photodegradation process was examined with Fourier Transform Infrared (FTIR) spectra. Acetylated hornbeam was less prone to crack, but the modification did not hinder the fading and greying caused by UV irradiation. Coating the samples with boiled linseed oil decreased the rate of colour change and cracking. The photodegradation of lignin was confirmed by the FTIR spectra.
\end{abstract}

hornbeam / acetylation / photodegradation / colour / boiled linseed oil / FTIR

Kivonat - Acetilezett és lenolajkencével kezelt gyertyán (Carpinus betulus L.) fotostabilitásának vizsgálata. A tanulmányban az acetilezés és lenolajkencés kezelés hatását vizsgáltuk a közönséges gyertyán (Carpinus betulus L.) faanyag fotodegradációs folyamataira vonatkozóan. A fotostabilitás vizsgálatához időjárásállósági tesztet végeztünk 10 hónapos kültéri kitettség során (talajjal való érintkezés nélkül), illetve mesterséges öregítést végeztünk 200 órás higanygőzlámpás besugárzással. A méréseket gyertyán, acetilezett gyertyán, lenolajkencével kezelt gyertyán és acetilezett és lenolajkencével kezelt gyertyán próbatesteken végeztük. A kezeletlen és kezelt próbatestek színváltozását minden esetben az eredeti színhez képest határoztuk meg. A fotodegradációs folyamatokat Fourier Transzformációs Infravörös Spektroszkópiával (FTIR) vizsgáltuk. Az acetilezett gyertyán kevésbé repedékeny, de a kezelés nem csökkentette az UV sugárzás okozta fakulás illetve szürkülés mértékét. A lenolajkencés kezelés mérsékelte a színváltozás és repedés mértékét. A lignin fotodegradációját az FTIR színképek alapján igazoltuk.

gyertyán / acetilezés / fotodegradáció / szín / lenolajkence / FTIR

\footnotetext{
* Corresponding author: fodor.fanni@phd.uni-sopron.hu; H-9400 SOPRON, Bajcsy-Zs. u. 4, Hungary
} 


\section{INTRODUCTION}

The aesthetic appearance of wooden products is greatly influenced by their colour. This is why consumers expect colour stability in wood products whether it be indoor furniture or outdoor decking. The colour of wood changes if it is exposed to ultraviolet (UV) light or thermal impact. The colour can be objectively determined by various methods. In this work, CIELAB colour system was used where $L^{*}$ defines lightness ( 0 is black and 100 is white), $a^{*}$ denotes red/green hue (positive values for red and negative values for green), and $b^{*}$ denotes yellow/blue hue (positive values for yellow and negative for blue). The colour change of wooden products can be determined by calculating the change in colour components $(\Delta \mathrm{L}, \Delta \mathrm{a}$, $\Delta \mathrm{b})$ and then the total colour difference $\left(\Delta \mathrm{E}^{*}\right)$. According to Terziev - Boutelje (1998) and Mononen et al. (2002), the difference can be seen with the naked eye if $\Delta \mathrm{E}^{*}$ is 2 or more. Jirouš - Ljuljka (1999) determined the levels of colour differences for paper, but these can be used for wood as well (Straže - Gorišek 2008). It should be noted that the difference between wooden surfaces cannot be noticed simply due to colour change, but also due to the inhomogeneity of wood itself (vessels, tyloses, ray flecks, grain structure, early and late wood transition).

If wood is exposed to natural weather, colour change is affected by the temperature, sunny hours, precipitation, rate of UV-A and UV-B radiation, the effect of insects collecting the loose cellulose fibres, etc. Lightness can have some initial increment, but it will decrease in the end. The surface starts to yellow at first, then it will grey after months due to the leaching of lignin and extractives, thus $a^{*}$ and $b^{*}$ decrease significantly (Tolvaj - Papp 1999, Tolvaj - Mitsui 2005).

UV degradation on uncoated and coated wood surfaces is due to the degradation of lignin in the cell wall. Lignin absorbs more UV energy than holocelluloses, and this energy is absorbed by double bonds, phenolic and carbonyl groups, quinones, quinone methids and biphenyls. The energy absorbance is affected by the density and the chemical composition of wood. During UV exposure, the photo-oxidation mechanism in lignin leads to demethylation and the formation of quinones (Rowell - Bongers 2015, Jawaid et al. 2017). As the lignin is degraded by UV light and washed away by rainwater, the surface cracks and the grey cellulose fibres become visible.

The advantage of artificial ageing is the reproducibility of the measurements, the constant settings and the short testing time. In these tests, artificial light sources like a xenon lamp, a mercury-vapour lamp, etc., are used. Unlike weather exposure, only photodegradation occurs during artificial ageing.

The colour of objects is determined by the conjugated double bonds in their chemical structure. These bonds are present in lignin and extractives. The colour of wood is mainly defined by the quantity and quality of extractives. The changes in the chemical structure can be examined by Fourier Transform Infrared (FTIR) spectroscopy. In recent decades, many researchers reported on the topic of photodegradation using a mercury-vapour lamp (Ohkoshi 2002, Colom et al. 2003, Tolvaj et al. 2011, Tolvaj 2013). The degradation of lignin is presented by the reduction in absorption of guaiacyl lignin $\left(1510 \mathrm{~cm}^{-1}\right)$ and syringyl lignin $\left(1600 \mathrm{~cm}^{-1}\right)$. This phenomenon is always accompanied by the formation of quinones and the increase of carbonyl groups absorption (Popescu et al. 2011).

Acetylation is a chemical wood modification method that improves the durability, dimensional stability and strength of wood without being toxic to the environment (Hill 2006). During the process, the wood is impregnated with a liquid reagent using vacuum and pressure so that it becomes integrated in the wood, modifying its chemical structure and properties. At the industrial level, acetic anhydride is used (Accsys Technologies, the Netherlands). When acetic anhydride reacts with the hydroxyl $(\mathrm{OH})$ groups in the cell wall, 
acetyl groups form. These are bigger molecules than $\mathrm{OH}$ groups, which results in a denser, heavier wood material. The properties of acetylated wood are generally given according to its WPG (Weight Percentage Gain) as the physical and mechanical properties usually improve by increasing the WPG (Hill et al. 2004, Hill 2006).

The colour of wood does not necessarily change significantly after acetylation unlike in the case of thermal modification, which is done at lower temperatures. Broadleaved species usually darken at a higher rate than coniferous species, and dark-coloured species usually become brighter while light-coloured species usually darken (Mitsui 2010, Rowell 2013, Fodor 2015, Dong et al. 2016).

After acetylation, the absorption of carbonyl groups $\left(1740 \mathrm{~cm}^{-1}\right)$ and methine $(\mathrm{CH})$, methylene $\left(\mathrm{CH}_{2}\right)$, methyl $\left(\mathrm{CH}_{3}\right)$ groups $\left(2970 \mathrm{~cm}^{-1}\right)$ increase while the absorption of the functional groups of lignin decrease (Mohebby - Radjihassani 2008, Fodor et al. in press).

It is reported that acetylation increases the weather (light and moisture) resistance of wood (Leary 1968, Feist et al. 1991, Plackett et al. 1992, Dawson et al. 1992, Owen et al. 1993, Ota et al. 1996, 1997, Ohkoshi 2002, Rowell 2006), noting that the photostability increases at higher WPG levels (Dawson et al. 1992). However, acetylated wood only shows initial stability against UV radiation; later, it begins to fade and grey (Kalnins 1984, Dunningham et al. 1992, Hon 1995, Torr et al. 1996, Ota et al. 1996, 1997, Ohkoshi 2002, Mitsui - Tolvaj 2004, 2005). This is also true for Accoya ${ }^{\circledR}$ Radiata pine (Meyer 2006, Lahtela - Kärki 2015). The colour change caused by photodegradation is influenced by the structural change of extractives too. According to Guo - Guan (2010), the degradation of lignin is hindered due to acetylation and the increased moisture resistance and dimensional stability also restrains the photodegradation mechanism of wood. On the other hand, acetylating the phenolic $\mathrm{OH}$ groups, which retard the formation of quinones, reduce this protective mechanism ( $\mathrm{Pu}$ - Ragauskas 2005, Rowell 2005). This makes acetylated wood vulnerable to colour change and greying even at high WPG levels (Placket et al. 1992). Feist et al. (1991) found that acetylation only protects lignin to a small extent while protecting hemicellulose (xylan) to a greater extent during UV radiation. Acetylated wood exposed to weather or irradiation needs to be treated with dark, pigmented wood finish in order to stabilize its colour (Rowell - Bongers 2015).

In this work, a mercury-vapour lamp was used for the irradiation of wood. This creates a stronger colour change in a shorter time compared to a xenon lamp or natural sunlight. This is because the mercury-vapour lamp has a different wavelength emission. Unlike a xenon lamp, it emits light in all UV regions. UV light amounts to $80 \%$ of its emission, from which $31 \%$ is in the UV-A (380-315 nm) region, $24 \%$ is in the UV-B $(315-280 \mathrm{~nm})$ region, and $25 \%$ is in the UV-C (> $280 \mathrm{~nm})$ region.

Boiled linseed oil is a mixture of linseed oil, stand oil, and metallic dryer to accelerate drying. These solvents cause linseed oil to dry more quickly, acting as if it were "boiled". Regular linseed oil can take weeks or sometimes months to cure depending on the weather conditions. According to Treu et al. (2004), boiled linseed oil significantly reduces the degradation and staining of wood when exposed to brown rot and blue stain. It deepens the colour of wood and protects it from UV and moisture. It is easy to handle, but its flammability needs to be considered during usage. It penetrates deeply into the wood, which is why it is mainly used as a sealant before the application of other coatings. In this work, it was chosen as a preliminary test for the coatability and colour change of acetylated hornbeam.

The aim was to examine the effect acetylation and boiled linseed oil coating have on the photostability of hornbeam wood. The samples were exposed to natural sunlight and weather, and also to artificial irradiation (mercury-vapour lamp). The rate of photodegradation was evaluated according to the change of colour components and FTIR differential spectra. 


\section{MATERIALS AND METHODS}

Edged and air-dry hornbeam boards were ordered from a Hungarian sawmill (BOPAÁR Ltd.). The dimensions were $27 \times 160 \times 2500 \mathrm{~mm}$ (thickness $\times$ width $\times$ length). Half of the boards were left untreated and the other half was sent to Accsys Technologies to be acetylated under industrial conditions. The average WPG was $15 \%$.

For the tests, half of the samples were coated with boiled linseed oil (from Köházy Tradíció Ltd.). The oil coating was applied two times (as it was recommended by the manufacturer) with one day drying time to ensure better penetration.

\subsection{Weather exposure}

The samples were put to exposure without soil contact in the Outdoor Exposure Testing Field of the Department of Wood Science in 2016 July. The tests were carried out according to Csizmadia (2015): the samples were of $20 \mathrm{~mm} \times 45 \mathrm{~mm} \times 200 \mathrm{~mm}$ (thickness $\times$ width $\times$ length) with planed, smooth, tangential surface. There were five circles marked on each sample for colour measurement. Small spacers provided air gap between the samples.

There were 10 hornbeam (marked $\mathrm{H}$ ), 10 acetylated hornbeam (A), 10 boiled linseed oiltreated hornbeam $(\mathrm{H}+\mathrm{BLO})$, and 10 boiled linseed oil-treated and acetylated hornbeam $(\mathrm{A}+\mathrm{BLO})$ samples. They were placed on metal stands tilted at $45^{\circ}$. The colour measurement and visual inspection of the samples were done every month, in their current state, without conditioning.

The colour was expressed in CIE L*a*b* colour space with X-Rite SP60 Portable Colorimeter and Colour iControl program. The colorimeter's sensor head was $8 \mathrm{~mm}$. The colour was measured and calculated based on the D65 illuminant and $10^{\circ}$ standard observer.

\subsection{Mercury-vapour lamp irradiation}

The UV irradiation was carried out in an ageing machine at the Department of Physics and Electronics at the University of Sopron. There were two mercury-vapour lamps used (800 Watt), which were $64 \mathrm{~cm}$ above the samples. The temperature of the equipment was set to $50^{\circ} \mathrm{C}$.

The samples were of $20 \mathrm{~mm} \times 45 \mathrm{~mm} \times 140 \mathrm{~mm}$ (thickness $\times$ width $\times$ length) with planed, smooth, tangential surface. There were five circles marked on each sample for colour measurement done as described above.

The samples for FTIR spectroscopy were of $5 \mathrm{~mm} \times 10 \mathrm{~mm} \times 30 \mathrm{~mm}$ (thickness $\times$ width $\times$ length) with planed, smooth, radial surface. For the measurements JASCO FT/IR-6300 spectrometer and Spectra Manager program was used. The final spectra of each sample was the average of 45 measurements.

The colour and FTIR measurement was determined after 0-5-10-20-30-60-120-200 hours of irradiation.

\section{RESULTS AND DISCUSSION}

As a result of acetylation, the colour of hornbeam became darker, greyish brown. The ray flecks became darker; the wavy grain has become more prominent to the naked eye. The modification process affected the whole cross section. The outer layer of wood (2-3 $\mathrm{mm})$ was darker, but it was removed after further processing.

\subsection{Weather exposure}

The samples were already exposed to strong sunlight in the first month (July), which resulted great colour change. 
The change of colour coordinates and colour change is shown in Figure 1 according to exposure time. Figure 2 indicates the shifting of red and yellow hue as an effect of photodegradation.
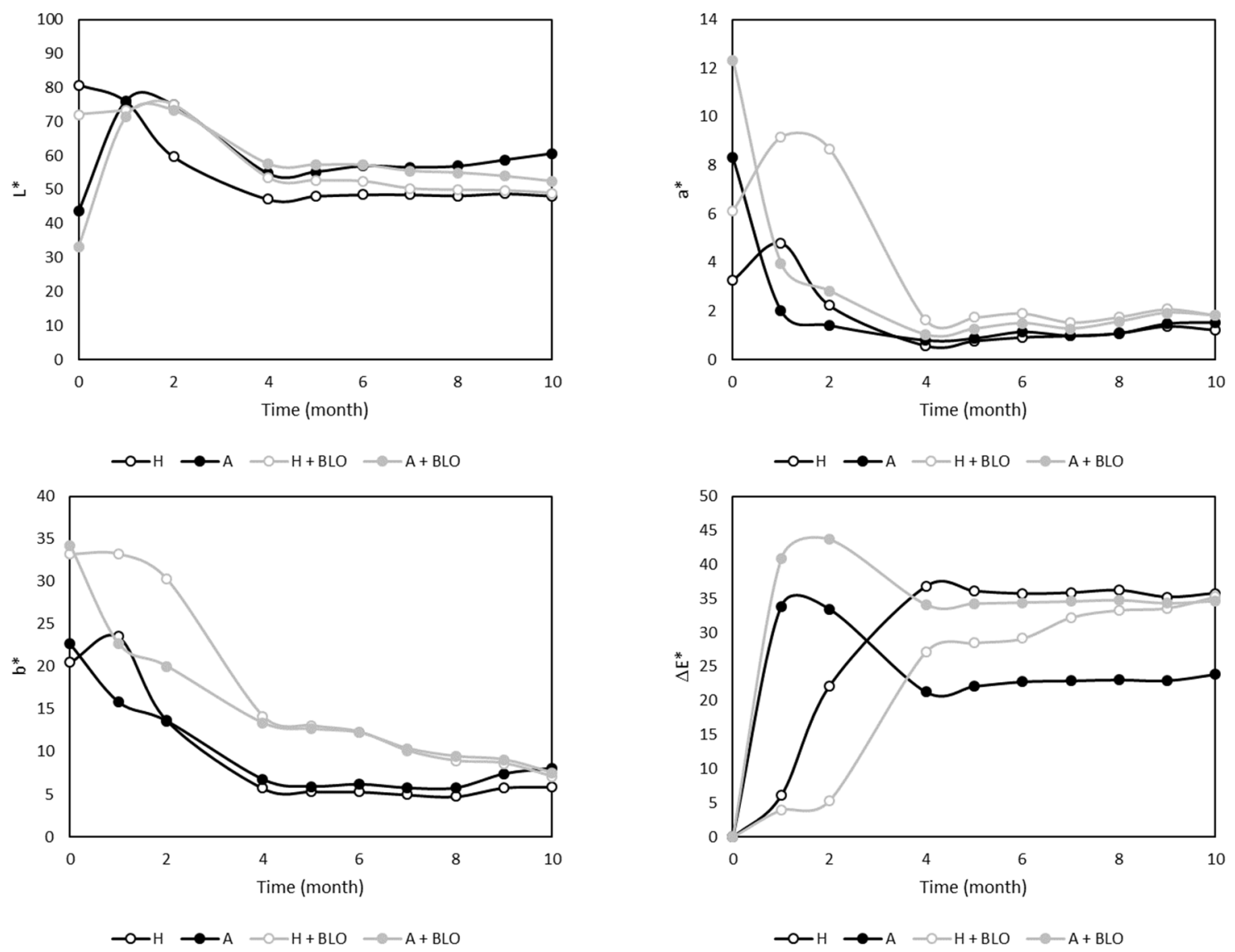

Figure 1. Change of colour coordinates during weather exposure. The measurements started in July 2016 ( $L^{*}$ : lightness, $a^{*}$ : red hue, $b^{*}$ : yellow hue, $\Delta E^{*}$ : colour difference of the actual and the original colour, $H$ : hornbeam, A: acetylated hornbeam, untreated or BLO: coated with boiled linseed oil)
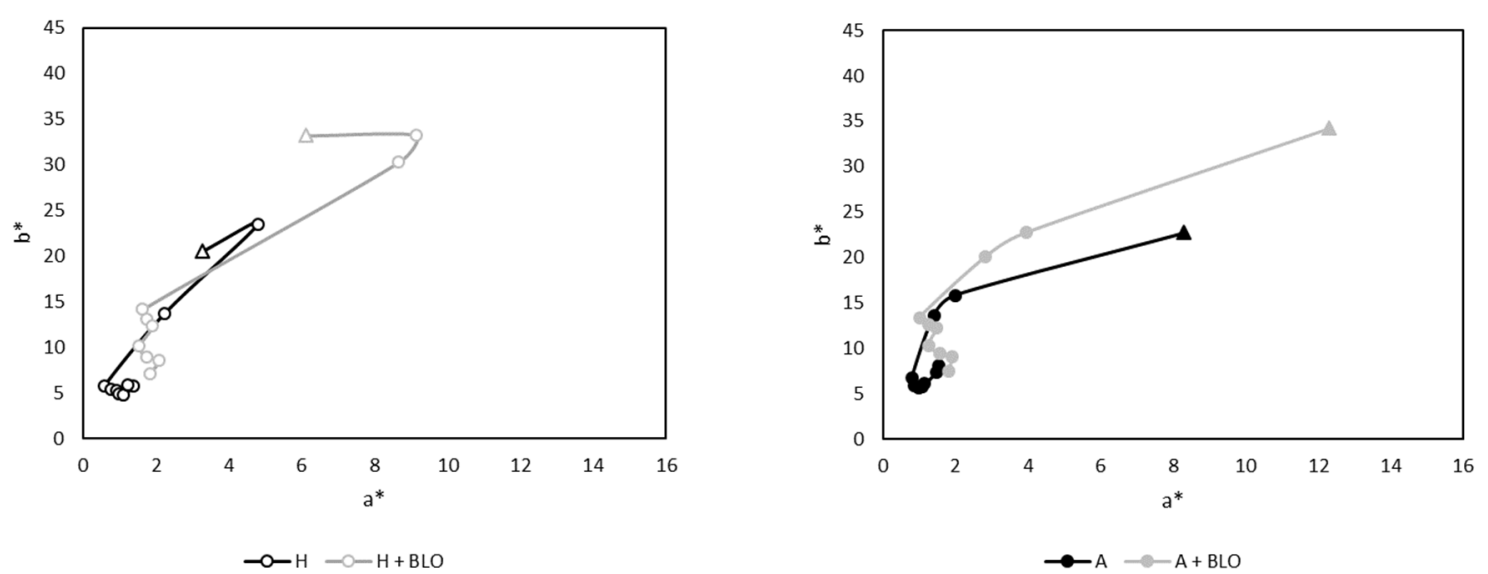

Figure 2. Change of red ( $\left.a^{*}\right)$ and yellow $\left(b^{*}\right)$ colour points during weather exposure. The points marked with triangles represent the colour points of the original sample, then it is followed by the colours measured in the $1^{\text {st }}, 2^{\text {nd }}, 3^{\text {rd }}$, etc. month. (H: hornbeam, A: acetylated hornbeam, untreated or BLO: coated with boiled linseed oil) 
The hornbeam samples were cracked, moulded and faded after the first month exposure. The linseed oil-covered samples had a deeper yellow colour than untreated hornbeam. The red and yellow hue initially increased then decreased in the cases of both samples (Figure 1 and Figure 2). The surfaces gradually greyed and moulded in the months following. In the final months, long and deep cracks appeared on the end grain and sides as well. The shape and dimensions of the samples changed. Small wasp damages are visible in some cases.

Despite the improvement of strength and durability properties, acetylation did not increase the photostability of hornbeam wood. Prominent fading was already experienced in the case of acetylated and also acetylated and coated samples in the first month (July). Coating acetylated wood with boiled linseed oil eased the rate of photodegradation (Figure 1). In the months following, the samples greyed gradually. The change of temperature and humidity did not affect the shape and size of the acetylated samples. Some small hairline cracks appeared in the final months.

By coating the wood with boiled linseed oil, no cracks formed on the surface and the samples had better resistance to moisture (Figure 3). The red and yellow hue gradually decreased and the grey colour stabilized after the fourth month (Figure 2). The coating did not stop the rate of degradation, it just hindered it. The coated surfaces which were not exposed directly to weather - but contacted the metal stand - preserved their original colour, unlike the uncoated samples.
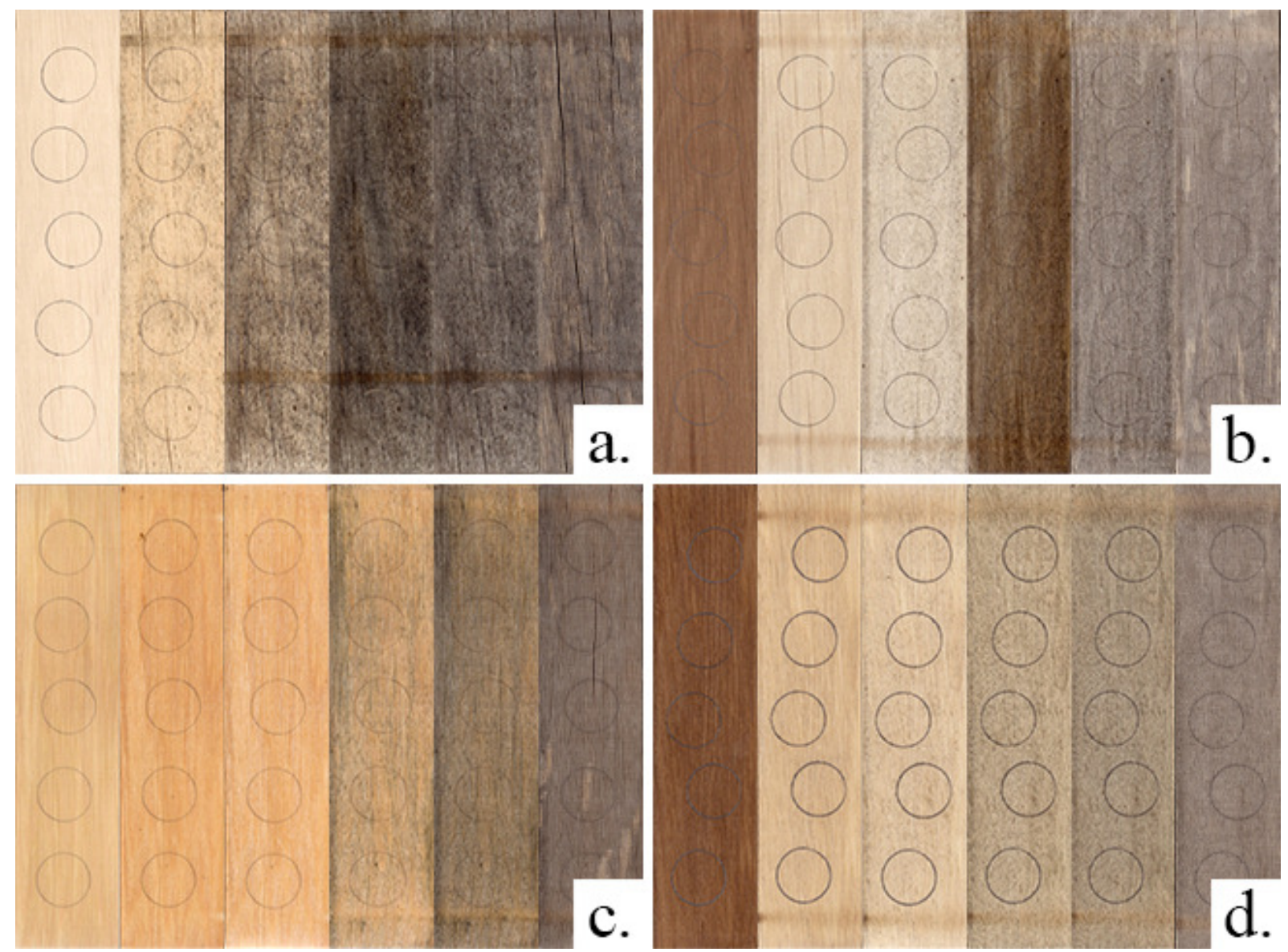

Figure 3. Series of photos of hornbeam samples exposed to weather. It shows the scans of the samples before exposure, and 1, 2, 3, 4 and 10 months after the exposure (a.: untreated hornbeam, b.: acetylated hornbeam, c.: hornbeam coated with boiled linseed oil, d.: acetylated hornbeam coated with boiled linseed oil) 
In the third month (October), heavy rain occurred, which affected the colour change of the samples (Figure 3). Here the measured data has big variation because of the moist surface so it was excluded from the results. According to various studies (Hon - Minemura 2001, McCurdy et al. 2006, Teischinger et al. 2012, Németh et al. 2013, Tolvaj 2013) the increase of moisture content and the wetting of the surface makes the wood more vivid, as it reduces the lightness and increases the red and yellow hue. The rain leaches out the water-soluble extractives, which define the colour of wood, and also the photodegradation products.

\subsection{Mercury-vapour lamp irradiation}

After 5 hours of mercury-vapour lamp irradiation, the colour changed remarkably, especially in the case of acetylated hornbeam coated with boiled linseed oil. The rate of colour change decreased over time (Figure 4).
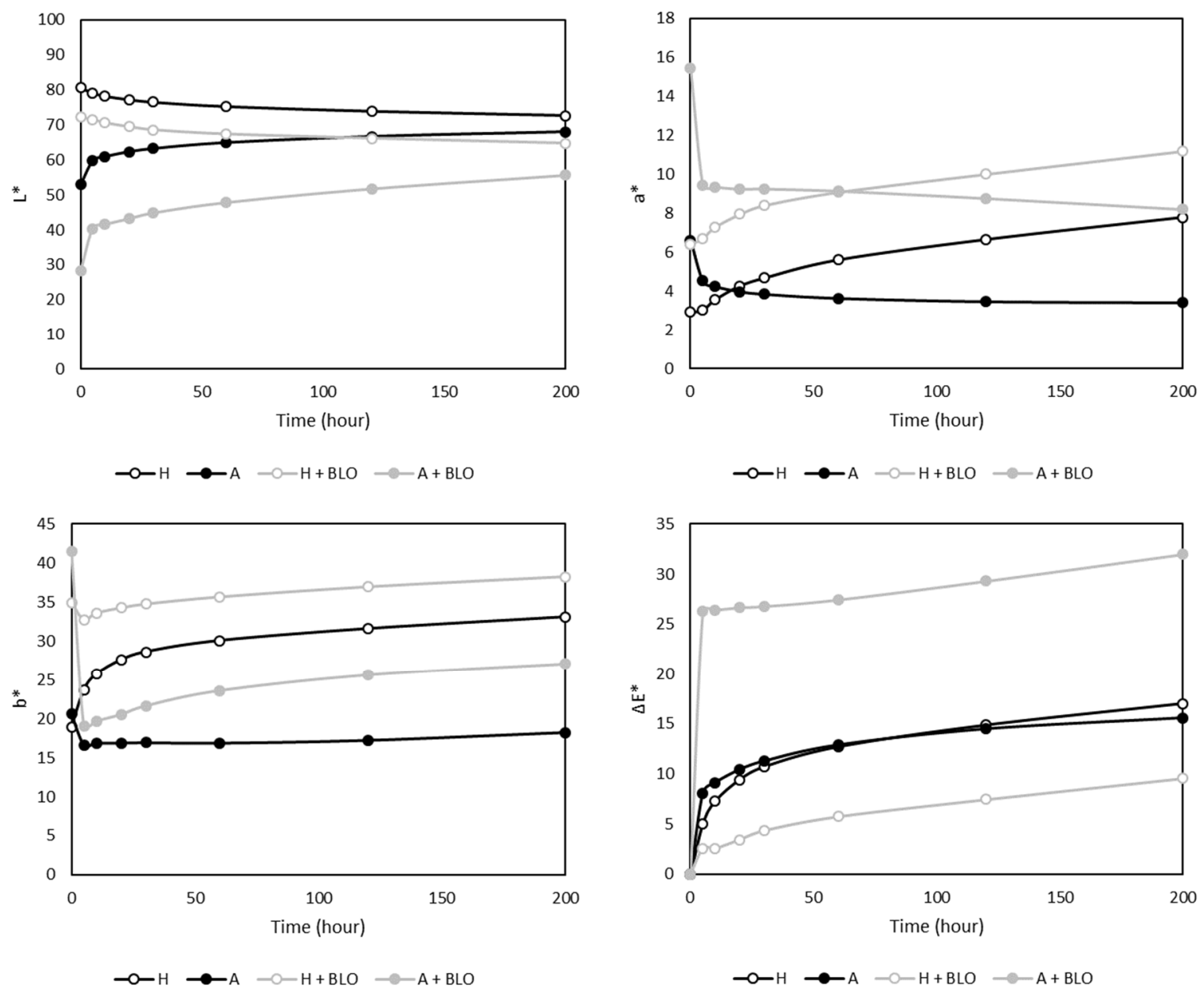

Figure 4. Change of colour coordinates during mercury-vapour lamp irradiation ( $L^{*}$ : lightness, $a^{*}$ : red hue, $b^{*}:$ yellow hue, $\Delta E^{*}$ : colour difference of the actual and the original colour, $H$ : hornbeam, A: acetylated hornbeam, untreated or BLO: coated with boiled linseed oil)

During irradiation, hornbeam's light colour became a darker yellow. The lightness decreased while the red and yellow hue increased (Figure 4). Figure 5 shows the shifting of the yellow and red hue during irradiation. The colour of hornbeam coated with boiled linseed oil changed similarly, the brightness decreased, the red hue increased, while the yellow hue 
initially (in the first 5 hours) decreased and then increased. Coating hornbeam wood with boiled linseed oil improved its colour stability (Figure 6).

Acetylated hornbeam's dark greyish brown colour brightened greatly as a result of mercury-lamp irradiation. The biggest colour change was measured in the first 5 hours. The lightness increased, the red hue decreased, the yellow hue initially decreased then increased (Figure 4). The biggest total colour change was in case of coated and acetylated hornbeam (Figure 4). The change of its colour components were similar to acetylated hornbeam, but the shifting of red and yellow hue was more prominent (Figure 5).
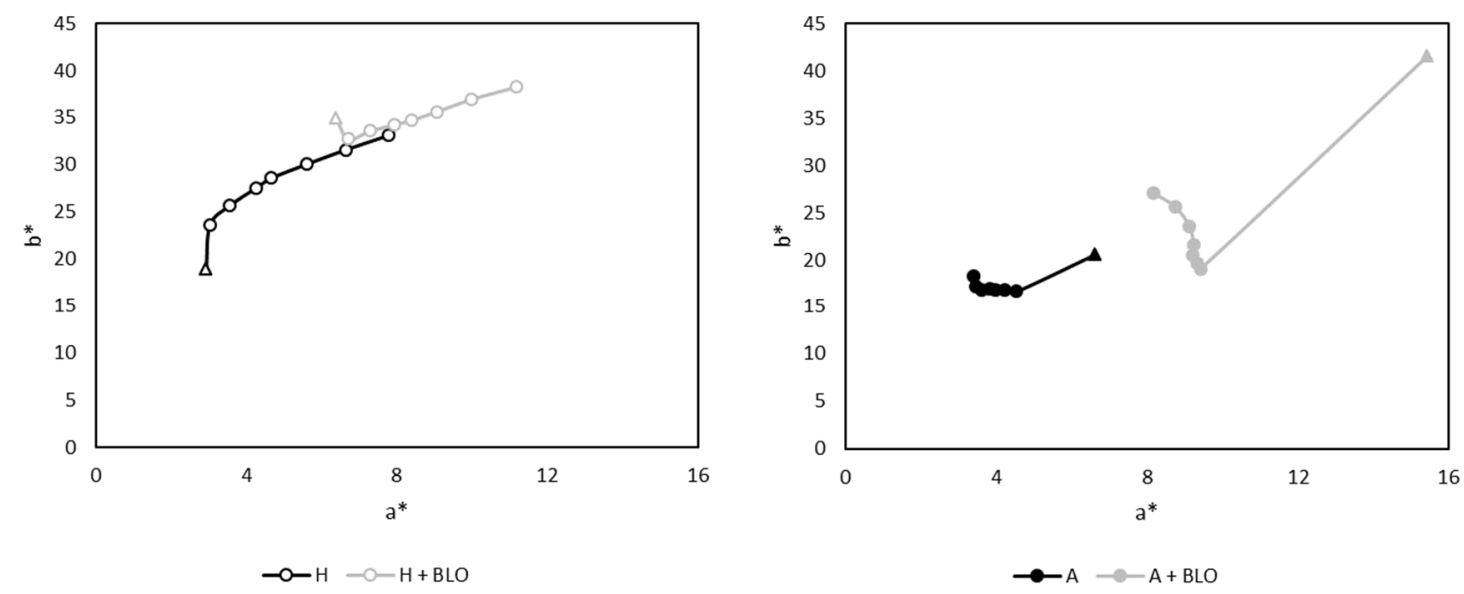

Figure 5. Change of red ( $\left.a^{*}\right)$ and yellow $\left(b^{*}\right)$ colour points during mercury-vapour lamp irradiation. The samples are of untreated or acetylated hornbeam, with or without boiled linseed oil coating. The points marked with triangles represent the colour points of the original sample, which is then it is followed by the colours measured in the $5^{\text {th }}, 10^{\text {th }}$, etc. hours (H: hornbeam, A: acetylated hornbeam, untreated or BLO: coated with boiled linseed oil)

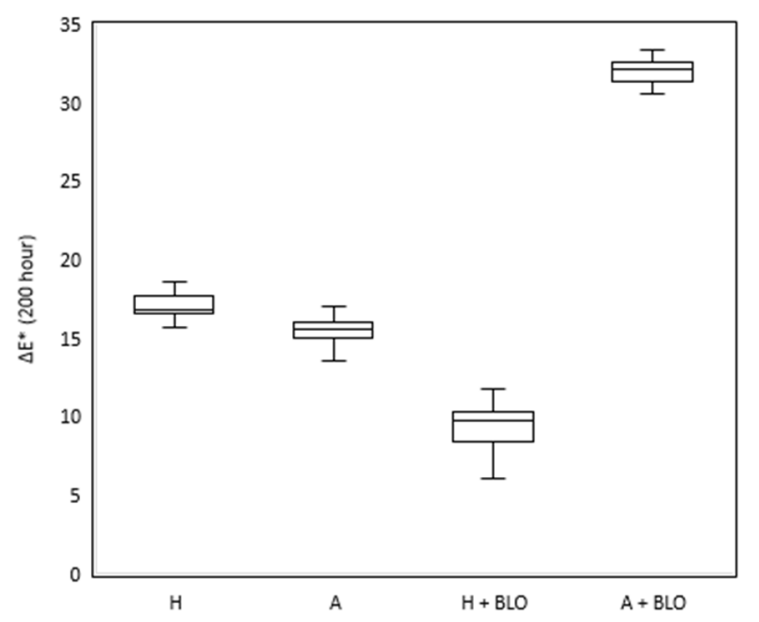

Figure 6. Box diagram of the colour changes ( $\left.\Delta E^{*}\right)$ caused by 200 hours mercury-vapour lamp irradiation compared to the original colour (H: hornbeam, A: acetylated hornbeam, untreated or BLO: coated with boiled linseed oil, the boxes are bounded on the top by the third quartile, and on the bottom by the first quartile, the box is divided by the median, the whiskers represent the maximum and minimum) 
Figure 7. shows the scans of one sample from each type before and after 200 hours of irradiation. The yellowing of hornbeam and brightening of acetylated hornbeam is visible to the naked eye.
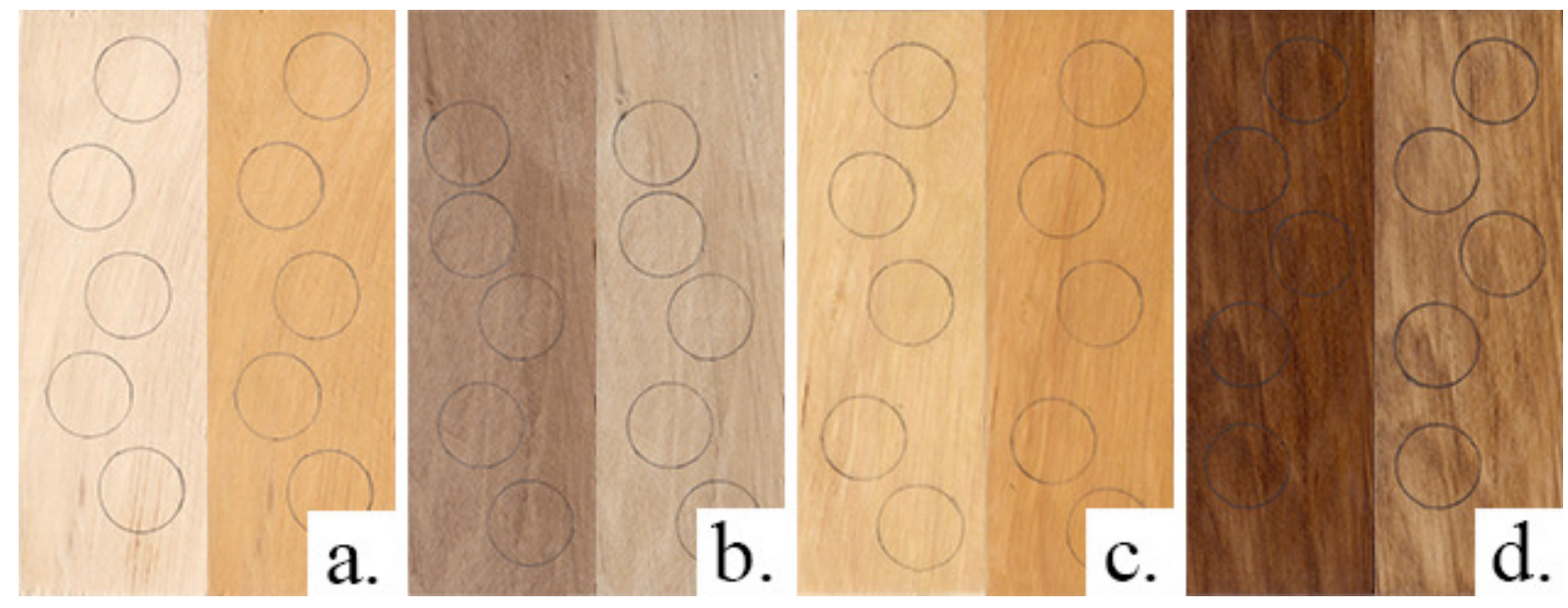

Figure 7. Photos of hornbeam samples before and after being exposed to 200 hours of mercury-vapour lamp irradiation (a.: untreated hornbeam, b.: acetylated hornbeam, c.: hornbeam coated with boiled linseed oil, d.: acetylated hornbeam coated with boiled linseed oil)

The colour change induced by natural weathering and artificial ageing (mercury-vapour lamp) has similar results or tendency, but in the case of weather exposure, the colour is influenced by many other factors besides UV radiation. The exposure to real conditions is more useful for industry rather than for laboratory tests, which lack these factors. On the other hand, the weathering tests are non-repeatable and uncontrollable, which makes it difficult to compare results. The sunlight (UV radiation) causes the greatest change in the colour and the surface. The mercury-vapour lamp can help study the photodegradation mechanism in wood, but it cannot simulate natural sunlight (Tolvaj - Persze 2011, Tolvaj - Varga 2012). During irradiation, the leaching of lignin and extractives does not take place, which greys the surface. The colour obtained after 200 hours of irradiation is obtained in less than 1 month of weather exposure.

The FTIR spectra was measured before irradiation and after each phase (5-10-20-30-60120-200 hours). The changes were determined according to differential spectra, which was calculated by subtracting the initial (non-irradiated) spectra from the irradiated spectra (Figure 8.). In each spectrum, the peaks and absorption bands were determined (Table 1) and marked with numbers on each diagram and in the text.

According to previous studies (Fodor 2015), the moisture content of hornbeam is greatly reduced due to the bulking of the cell wall during acetylation. As the cell wall's $\mathrm{OH}$ groups were replaced by acetyl groups, the weight increased by 15\% (WPG). During UV irradiation, the hydrogen bonds were broken and the $\mathrm{OH}$ groups changed and rearranged in the system, which is indicated by the positive and negative peaks in the spectra (1). There are bigger peaks (differences) in the differential spectrum of acetylated hornbeam than in untreated hornbeam.

The absorption of methine $(\mathrm{CH})$, methylene $\left(\mathrm{CH}_{2}\right)$ and methane $\left(\mathrm{CH}_{3}\right)$ groups (2) increased after UV-B and UV-C irradiation. This band is usually not affected by photodegradation. The reason for this absorption change may be due to the fact that this band cannot be separated from the band of OH stretching (Tolvaj - Faix 1995).

A previous research study proved that there was no significant degradation in the cellulose of hornbeam after acetylation (Fodor 2015). The spectra show a reduction in 
symmetrical C-H deformation (8), asymmetric C-O-C stretching (12), and symmetric C-O-C stretching (13), but an increase in $\mathrm{C}-\mathrm{H}$ deformation (9) and $\mathrm{C}-\mathrm{O}$ stretching (14). Cellulose is more resistant to photodegradation; thus, the reduction of these absorption bands are associated with the change in hemicellulose.
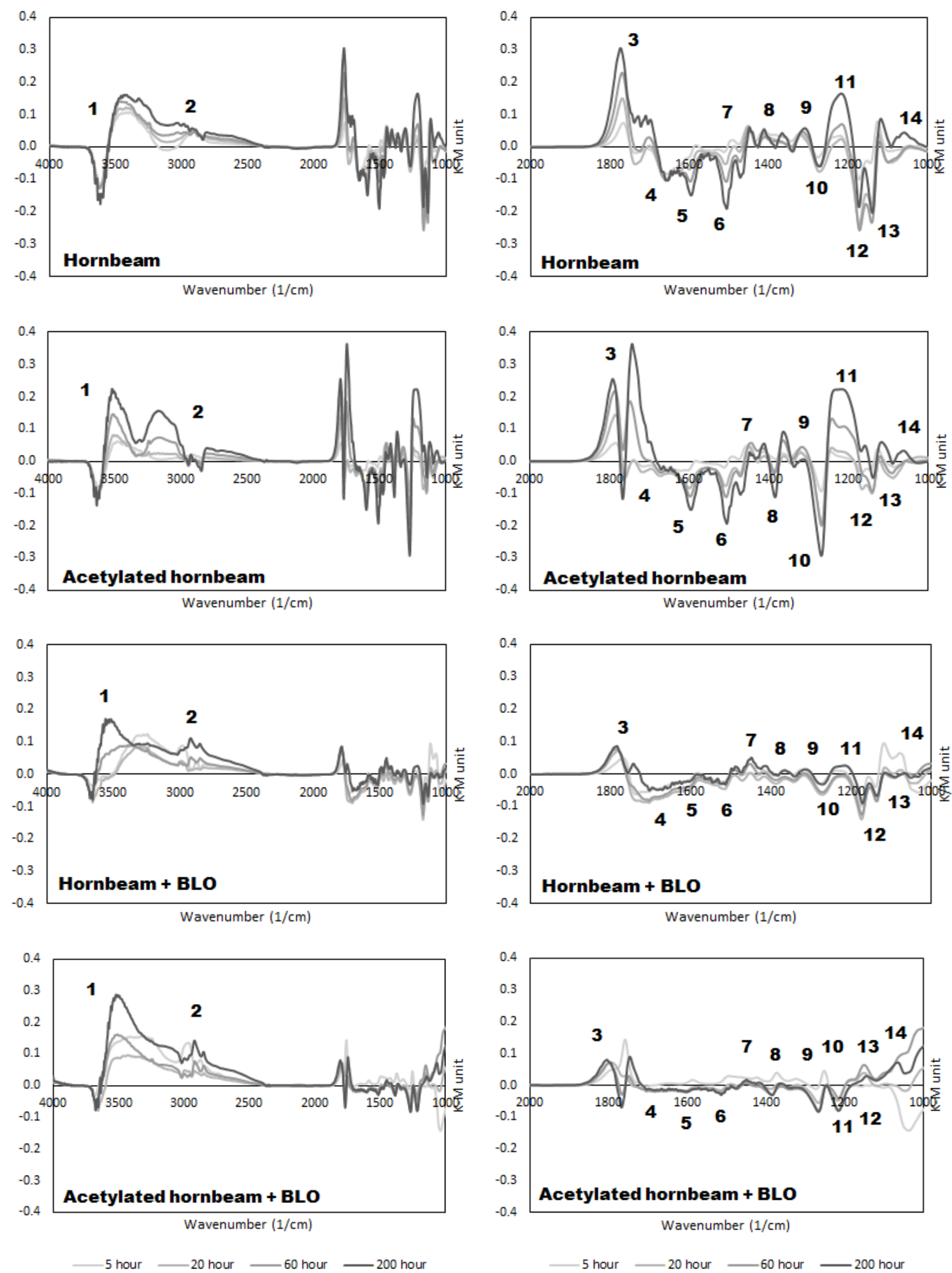

Figure 8. Change of hornbeam samples' FTIR difference spectra during 200 hours of mercury-vapour lamp irradiation (BLO: coated with boiled linseed-oil) 
Table 1. Wavenumber characterization of the infrared spectra of hornbeam samples according to Tolvaj (2013).

\begin{tabular}{|c|c|c|c|}
\hline $\begin{array}{l}\text { Band } \\
\text { number }\end{array}$ & $\begin{array}{l}\text { Wavenumber } \\
(1 / \mathrm{cm})\end{array}$ & Functional group & Assignment \\
\hline 1 & $3677-3152$ & Hydroxyl group $(\mathrm{OH})$ stretching & Cellulose, hemicellulose, lignin \\
\hline 2 & $2983-2844$ & $\mathrm{CH}$ stretching & $\begin{array}{l}\text { Methine }(\mathrm{CH}) \text {, methylene } \\
\left(\mathrm{CH}_{2}\right) \text {, methyl }\left(\mathrm{CH}_{3}\right) \text { groups }\end{array}$ \\
\hline 3 & $\begin{array}{l}1804-1773 \\
1745-1698\end{array}$ & $\begin{array}{l}\text { Unconjugated } \mathrm{C}=\mathrm{O} \\
\text { (carbonyl group) stretching }\end{array}$ & Xylan \\
\hline 4 & $1675-1658$ & $\begin{array}{l}\text { Conjugated } \mathrm{C}=\mathrm{O} \\
\text { (carbonyl group) stretching }\end{array}$ & Xylan \\
\hline 5 & 1604-1596 & Aromatic skeletal vibration & Syringyl lignin \\
\hline 6 & $1514-1495$ & Aromatic skeletal vibration & Guaiacyl lignin \\
\hline 7 & $1476-1411$ & Asymmetric C-H deformation & Lignin, carbohydrates \\
\hline \multirow[t]{3}{*}{8} & $1397-1383$ & Symmetric C-H deformation & Cellulose and hemicellulose \\
\hline & & C-H deformation & Cellulose \\
\hline & & $\mathrm{C}-\mathrm{OH}$ vibration & Syringyl derivatives \\
\hline 10 & $1279-1266$ & Ring vibration & Guaiacyl lignin \\
\hline 11 & $1219-1215$ & C-O stretch & Xylan \\
\hline \multirow[t]{3}{*}{12} & $1176-1159$ & Asymmetric C-O-C stretching & Cellulose and hemicellulose \\
\hline & & Symmetric C-O-C stretching & Cellulose and hemicellulose \\
\hline & & Aromatic C-H skeletal vibration & Lignin \\
\hline 14 & $1102-1067$ & C-O vibration & Cellulose and hemicellulose \\
\hline
\end{tabular}

According to Fodor et al. (in press), the absorption of conjugated carbonyl groups decreases slightly in wood after acetylation, probably due to minor degradation of xylans in acidic medium. As a result of UV irradiation, the aromatic rings of lignin rupture, carboxyl groups and/or lactones form; thus, the absorption of carbonyl groups increases (Tolvaj - Faix 1995). The unconjugated carbonyl region has two distinct wavenumber ranges at $1800-1760 \mathrm{~cm}^{-1}$ and $1740-1700 \mathrm{~cm}^{-1}$ (3). In the case of acetylated hornbeam, the absorption at $1743 \mathrm{~cm}^{-1}$ is higher than at $1793 \mathrm{~cm}-1$. The absorption of hornbeam is smaller at $1698 \mathrm{~cm}-1$ than at $1773 \mathrm{~cm}^{-1}$. In every case, the absorption of conjugated carbonyl groups decreased (4). These peaks are less prominent in the case of samples coated with boiled linseed oil. After acetylation the amount of carbonyl groups increased, thus the rate of photodegradation was higher. In the case of non-acetylated samples, the thermally unstable acetyl groups degraded, which indicates the reduction of carbonyl groups. There are positive and negative peaks as well in $\mathrm{C}-\mathrm{H}$ deformation (8), C-O stretching (11), asymmetric C-O-C stretching (12), and symmetric C-O-C stretching (13) in hemicellulose; this can be due to the rupture of etheric bonds and reformation in the system.

During acetylation, some parts of lignin can dissolve in the acidic medium (Rowell 2005). The structural change and degradation of lignin was indicated by low absorption of aromatic functional groups in the study of Fodor et al. (in press). As a result of mercury lamp irradiation, the aromatic rings of lignin ruptured, which is indicated by lower absorptions in syringyl (5) and guaiacyl (6) lignin, asymmetric C-H deformation in lignin at 1476-1470 $\mathrm{cm}^{-1}$ (7), ring vibration in guaiacyl lignin (10) and aromatic $\mathrm{C}-\mathrm{H}$ skeletal vibration (13). The absorption reduction in samples coated with boiled linseed oil is less notable.

Alterations of the lignin structure can also account for the slightly darker, walnut-like colour of acetylated hornbeam. These changes can include the oxidation of the phenolic skeletal system as an effect of heat and acidic medium, as well as the reaction of lignin with 
evolving furfural in strong acidic medium (Dongre et al. 2015, Fodor et al. in press), which results in not only structural changes of lignin, but also alterations in the colour of wood. However, the strength and stiffness properties of acetylated hornbeam increased (Fodor 2015), which indicates the degradation of lignin was not significant. The brightening of acetylated hornbeam during weather exposure and mercury lamp irradiation is probably associated with the extractive content. After acetylation, the extractive content of hornbeam increased (Fodor et al. in press), which transformed during UV irradiation, thus influencing the colour. This effect was somewhat eased by coating it with boiled linseed oil.

The weather exposure tests are continuously carried out until no significant difference is measured between the samples (starting from July 2016). In the future, other sealants and varnishes are to be tested on acetylated hornbeam that are natural, non-toxic and pigmented.

\section{CONCLUSIONS}

The aim of this work was to examine the effect of acetylation and boiled linseed oil treatment on the photodegradation of hornbeam wood. A 10-month-long outdoor weather exposure test and a 200 hour mercury-vapour lamp irradiation test were carried out. The measurements were done on hornbeam and acetylated hornbeam, with or without boiled linseed oil coating.

According to our results, during UV irradiation hornbeam yellowed, the red hue (a*) and yellow hue $\left(b^{*}\right)$ increased. During weather exposure, where the fluctuation of temperature and moisture is frequent, hornbeam wood cracked, discoloured, and greyed in the end. The greying of wood is due to the bleaching of lignin leaving the grey cellulose chains on the surface.

Acetylated hornbeam did not crack during the exposure to frequently changing weather, but it had worse colour stability than native hornbeam. The dark, greyish brown colour of acetylated hornbeam brightened during UV irradiation because of the transformation of extractives and degradation of lignin. Unlike hornbeam, its brightness increased while the red and yellow hue decreased.

Coating the samples with boiled linseed oil decreased the rate of colour change and cracking. It is best to use it as a sealant and combine it with other outdoor finishes.

According to the FTIR spectra, lignin did degrade during mercury-vapour lamp irradiation. The absorption of functional groups in lignin decreased while that of methane, methylene, methyl and carbonyl groups increased. The rate of degradation and structural changes were highest in case of acetylated samples, but the strengthening polymers did not degrade notably.

Acknowledgements: This work was supported by the ÚNKP-16-3-1 New National Excellence Program of the Ministry of Human Capacities.

\section{REFERENCES}

Colom, X. - CARrillo, F. - Nogués, F. - Garriga, P. (2003): Structural analysis of photodegraded wood by means of FTIR spectroscopy. Polymer Degradation and Stability 80 (3): 543-549.

CsIZMADIA, P. (2015): Hőkezelt és kezeletlen faanyagok kültéri kitettségi vizsgálatai. [Outdoor exposure testing of heat-treated and untreated wood species.] Bachelor thesis. University of West Hungary, Simonyi Karoly Faculty, Institute of Wood Science. ID.: SKK-FATI-9-2015-SZ (in Hungarian)

DAWSON, B. - TORR, K. - PlacketT, D.V. - DunNingham, E.A. (1992): Spectroscopic and colour studies on acetylated radiata pine exposed to UV and visible light. In: Chemical modification of lignocellulosics. Rotorua, New Zealand, 07-08.11.1992. FRI-Bulletin No. 176. 
DONG, Y. - QIN, Y. - WANG, K. - YAN, Y. - ZHANG, S. - LI, J. - ZHANG, S. (2016): Assessment of the performace of furfurylated wood and acetylated wood: comparison among four fast-growing wood species. Bioresources 11 (2): 3679-3690.

Dongre, P. - Driscoll, M. - Amidon, T. - BujAnovic, B. (2015): Lignin-Furfural Based Adhesives. Energies 8 (8), 7897-7914.

DunNingham, E.A. - PlaCKETT, D.V. - SinGH, A. P. (1992): Weathering of chemically modified wood: natural weathering of acetylated radiata pine: preliminary results. Holz als Roh- und Werkstoff 50 (11): 429-432.

FEIST, W.C. - RowELL, R.M. - ElLIS, W.D. (1991): Moisture sorption and accelerated weathering of acetylated and methacrylated aspen. Wood and Fiber Science 23 (2): 128-136.

FODOR, F. (2015): Modification of hornbeam (Carpinus betulus L.) by acetylation. Master thesis. University of West Hungary, Simonyi Karoly Faculty, Institute of Wood Science.

FODOR, F. - NÉMETH, R. - LANKVELD, C. - HOFMANN, T. (in press): Effect of acetylation on the chemical composition of hornbeam (Carpinus betulus L.) in relation with the physical and mechanical properties. Wood Material Science and Engineering. DOI 10.1080/17480272.2017.1316773

GUO, M. - GUAN, X. (2010): Effect of UV-irradiation on Surface Colour and Chemical Structure of Wood. Advanced Materials Research 113-116: 1624-1628.

Hill, C.A.S. - PAPADOPOUlOS, A.N. - PAYNE, D. (2004): Chemical modification employed as a means of probing the cell-wall micropore of pine sapwood. Wood Science and Technology 37 (6): 475-488.

HILL, C.A.S. (2006): Wood Modification, Chemical Thermal and Other Processes. John Wiley \& Sons Ltd., Chichester. pp. 1-6, 17-23, 30-76.

HoN, D.N.S. (1995): Stabilization of wood colour: is acetylation blocking effective? Wood and Fiber Science 27 (4): 360-367.

Hon, D.N.S. - MinEMURA, N. (2001): Wood and cellulosic chemistry. New York, Marcel Dekker, pp. 385-442.

JAWAID, M. - TAHIR, P. - SABA, N. (2017): Lignocellulosic Fibre and Biomass-Based Composite Materials: Processing, Properties and Applications. Woodhead Publishing, Malaysia.

JIROUŠ-RAJKOVIĆ, V. - LJULJKA, B. (1999): Boja drva i njezine promjene prilikom izlaganja atmosferskim utjecajima, [The colour and the changes of colour of wood during weathering.] Drvna industrija, 50 (1): 31-39. (in Croatian)

KALNINS, M.A. (1984): Photochemical degradation of acetylated, methylated, phenylhydrazinemodified, and ACC-treated wood. Journal of Applied Polymer Science 29 (1): 105-115.

LAHTELA, V. - KÄRKI, T. (2015): Determination and comparison of some selected properties of modified wood. Wood research 60 (5): 763-772.

LEARY, G.J. (1968): The yellowing of wood by light: Part II. TAPPI 51: 257-260.

MCCURDY, M.C. - PANG, S. - KEEY, R.B. (2006): Surface colour change in wood during drying above and below fibre saturation point. Ciencia y tecnología 8 (1): 31-40.

Mitsui, K. - TOlVAJ, L. (2004): Application of acetylation to photo-thermal treatment. In: Proceedings of "3rd International Symposium on Surfacing and Finishing of Wood". Kyoto, Japan 24-26.11.2004. pp. 301-305.

Mitsui, K. - TOlvaJ, L. (2005): Colour changes in acetylated wood by the combined treatment of light and heat, Holz also Roh. und Werkstoff 63 (5): 392-393.

MiTSUI, K. (2010): Acetylation of wood causes photobleaching. Journal of Photochemistry and Photobiology B: Biology 101 (3): 210-214.

MoheBby, B. - RADJIHASSANI, R. (2008): Moisture Repellent Effect of Acetylation on Poplar Fibers. Journal of Agricultural Science and Technology 10 (2): 157-163.

Mononen, K. - Alvila, L. - TuUla, T. (2002): CIEL*a*b* Measurements to Determine the Role of Felling Season, Log Storage and Kiln Drying on Colouration of Silver Birch Wood. Scandinavian Journal of Forest Research 17 (2): 179-191.

NÉmeth, R. - OTT, Á. - TAKÁts, P. - BAK, B. (2013): The Effect of Moisture Content and Drying Temperature on the Colour of Two Poplars and Robinia Wood. Bioresources 8 (2): 2074-2083.

OHKOSHI, M. (2002): FTIR-PAS study of light-induced changes in the surface of acetylated or polyethylene glycol-impregnated wood, Journal of Wood Science 48: 394-401. 
OTA, M. - ABE, K. - SEKIGUCHI, T. (1996): Light-induced colour change of acetylated wood meal of kiri (Paulownia tomentosa Steud.). Mokuzai Gakkaishi 42 (2): 216-221.

OtA, M. - OgatA, H. - Jono, Y. - HiRotA, K. - ABE, K. (1997): Light-induced colour changes of acetylated veneers of kiri (Paulownia tomentosa Steud.), Mokuzai Gakkaishi 43 (9): 785-791.

OWEN, J.A. - OWEN, N.L. - FEIST, W.C. (1993): Scanning electron microscope and infrared studies of weathering in southern pine. Journal of Molecular Structure 300: 105-114.

PlacketT, D.V. - DunNingham, E.A. - SinGH, A.P. (1992): Weathering of chemically modified wood: accelerated weathering of acetylated radiata pine. Holz als Roh- und Werkstoff 50 (4): 135-140.

PU, Y. - RAGAUSKAS, A.J. (2005): Structural analysis of acetylated hardwood lignins and their photoyellowing properties. Canadian Journal of Chemistry 83: 2132-2139.

MeYer, R. (2006): Performance evaluation of acetylated wood from Titan Wood Ltd. Riba Lab Report number 12661.

POPESCU, C-M. - POPESCU, M-C. - VASILE, C. (2011): Structural analysis of photodegraded lime wood by means of FT-IR and 2D IR correlation spectroscopy. International journal of biological macromolecules 48 (4): 667-75.

Rowell, R.M. (2005): Handbook of Wood Chemistry and Wood Composites. Taylor and Francis. Boca Raton.

RowELL, R.M. (2006): Acetylation of wood - Journey from analytical technique to commercial reality. Forest Products Journal 56 (9): 4-12.

RowELL, R.M. (2013): Chemical modification of wood. In: Rowell, R. M. (szerk.) Handbook of wood chemistry and wood composites. CRC Press, Taylor \& Francis Group, Boca Raton, pp. 537-597.

ROWELL, R.M. - BONGERS, F. (2015): Coating acetylated wood. Coatings 5 (4): 792-801.

STRAŽE, A. - GORIŠEK Ž. (2008): Research colour variation of steamed cherrywood (Prunus avium, L.). Wood Research 53 (2): 77-90.

TERZIEV, N. - BOUTELJE, J. (1998): Effect of felling time and kiln-drying on colour and susceptibility of wood to mold and fungal stain during an above-ground field test. Wood and Fiber Science 30 (4): 360-367.

Teischinger A. - Zukal ML. - MeinTS T. - HANSMANn C. - Stingl R. (2012): Colour characterization of various hardwoods. In: Proceedings of "The 5th Conference on Hardwood Research and Utilization in Europe”. University of West Hungary; 10-11. 09. 2012. Sopron (HU) pp. 180-188.

TOLVAJ, L. - FAIX, O. (1995): Artificial Ageing of Wood Monitored by DRIFT Spectroscopy and CIE $L^{*} a * b *$ Colour Measurements. Holzforschung 49 (5): 394-404.

TOLVAJ, L. - PAPP, G. (1999): Outdoor Weathering of Impregnated and Steamed Black Locust. In: Proceedings of the "International Conference on the development of Wood Science, Wood Technology and Forestry". High Wycombe; Forest Products Research Centre, 14-16.07.1999. Missenden Abbey (UK) pp. 112-115.

TOlVAJ, L. - MitsuI, K. (2005): Light Source Dependence of the Photodegradation of Wood. Journal of Wood Science 51 (5): 468-473.

TOlvaJ, L. - Mitsui, K. - VARGA, D. (2011): Validity limits of Kubelka-Munk theory for DRIFT spectra of photodegraded solid wood. Wood Science and Technology 45 (1):135-146.

TOLVAJ, L. - PERSZE L. (2011): A napsugárzás mesterséges fényforrásokkal történő imitálásának problémája. [Problem of sunlight imitation by artificial light sources.] Faipar 59 (2-3): 19-26. (in Hungarian)

TOlVAJ, L. - VARGA, D. (2012): Photodegradation of Timber of Three Hardwood Species Caused by Different Light Sources. Acta Sylvatica et Lignaria Hungarica 8: 145-155.

TOLVAJ, L. (2013): A faanyag optikai tulajdonságai. [Optical properties of wood.] University of West Hungary, Faculty of Wood Sciences, József Cziráki Doctoral School of Wood Sciences and Technologies. (in Hungarian)

TORR, K.M. - DAWSON, B.S.W. - EDE, R.M. - SINGH, J. (1996): Surface changes on acetylation and exposure to ultraviolet radiation of Pinus radiata using X-ray photo-electron spectroscopy. Holzforschung 50 (5): 449-456.

TREU, A. - LÜCKERS, J. - MiLITZ, H. (2004): Screening of modified linseed oils on their applicability in wood protection. In: "The International Research Group on Wood Protection, 35th Annual Meeting”. Ljubljana, Slovenia. IRG/WP 04-30346: 1-17. 